\title{
OLIVER GARRISON RICKETSON, JR. - 1894-1952
}

Oliver Ricketson was born on September 19, 1894, in Pittsburgh, Pa., and died at Bar Harbor, Maine, on October 17, 1952. His parents were Oliver Garrison Ricketson, Senior, and Margaret Carnegie.

At the age of five, Oliver was taken to Cumberland Island, Ga., which is still owned by the heirs of his great uncle, Andrew Carnegie. Here he spent most of the next eight years in an isolated world of forests, wild animals, cattle, horses, and colored field hands - an admirable background for his future work in the jungles of Central America.

In 1907, Ricketson entered Middlesex School, where he became captain of the football team, graduating in 1912. At Harvard, he developed an interest in anthropology and was one of the first four students to take Professor Hooton's course in physical anthropology but, after graduating in 1916, he entered the Harvard Medical School.

Upon the declaration of war in April, 1917, Ricketson immediately enlisted in the navy as machinist mate. He served on the patrol ship Scoter which saw no action. After the war, he returned to the Medical School and completed the first year's work, but then decided that he did not want to be a doctor. Yet his medical training later proved most useful in Central America where he was called on to deliver babies and set broken bones.

In 1920 , Ricketson went west to live with the Wetheralls who then ran trading posts at Flagstaff and Kayenta. With them he cruised the Navajo reservation and was on the second expedition to reach the Rainbow Natural Bridge. - Eater he worked with Samuel Guernsey for the Peabody Museum, Harvard University, at Marsh Pass, Arizona, and with the Cartier expedition from the American Museum of Natural History in Arizona and Utah.

During this period, Ricketson met the late Dr. Sylvanus G. Morley of the Carnegie Institution of Washington. He accompanied Morley to Central America in 1921 as a mule skinner, thus becoming the first and only relative who has worked for any Carnegie foundation. Their journey across the base of the Yucatan peninsula was long and arduous. Afterwards Ricketson returned to Arizona for the summer, swearing never to set foot in the tropics again.

The following year, however, the enticement of a voyage to Tulum on the east coast of Yucatan brought him back in the Maya field. By this time, his talent for drawing and mapping had become recognized and he was beginning to take a technical interest in archaeology. On the 1922 expedition he made detailed maps of Tulum and Naranjo and worked on architectural surveys. Also he visited Uaxactun for the first time. After returning to the United States, he made his first voyage to Brazil to attend the XX International Congress of Americanists at Rio de Janeiro.

In 1923 Ricketson returned to the jungles of the Peten with W. A. Love and made the first accurate latitude and longitude surveys of the Maya cities. In the summer, with J. A. Jeancon, he covered a large part of the Southwest for the National Geographic Society, collecting samples for tree-ring datings. It was Ricketson who conceived the idea of taking borings in ancient beams at Oraibi and overcame local opposition by placing turquoise offerings in them. 
The next year was a busy one. After accom- Highlands. Ricketson's recommendations, pubpanying Frans Blom to Uaxactun, he carried out his first independent excavations - at Baking Pot, British Honduras - and he ended the field season at Chichen Itza, Yucatan, where the big Carnegie Institution program was getting under way. He also took his M.A. at Harvard.

The 1925 season again saw Ricketson at Chichen Itza, where he worked on repairs of the Caracol and the Temple of the Four Lintels and drawings of bas reliefs in the Northeast Colonnade. In August he married Miss Edith Hill Bayles from whom he was divorced in 1941. They went to Europe on their honeymoon and worked for some time in the British Museum.

In 1926, the Carnegie Institution of Washington negotiated a new contract with the Guatemalan government which initiated many years of excavation at the Maya ruins called Uaxactun with Ricketson in charge. Today there is an airport and a village with a post office at the site. At that time there was nothing, not even an adequate water supply. Everything - workmen, equipment and provisions - had to be transported from Belize by water in small boats and then on foot or mule back through the jungle for several days. Food shipped from the United States had to be ordered long in advance and so packaged that mules could carry it. Housés had to be built, crops planted both for men and mules. Ricketson, with his varied experiences and talents, was uniquely fitted for the task of successfully organizing the first big archaeological excavations in the tropical jungles of the New World.

Published accounts of Uaxactun are listed in the appended bibliography, and subsequent reports by A. L. and R. E. Smith have appeared. Ricketson's active leadership in the field terminated in 1929, when, after accompanying Col. Charles A. Lindbergh as observer on the pioneer reconnaissance of the Maya lowlands by plane, he moved to Guatemala City. There he spent a large part of the next seven years.

There were various reasons for this move. Ricketson's health had been impaired by long years in the jungle and he clearly needed to live in a more equitable climate. Also, the time had come to start studying the artifacts unearthed at Uaxactun, for which purpose he established a laboratory, which later was expanded on several occasions. Furthermore, a plan was to be set up for field work in the lished in 1931, were subsequently carried out for the most part by other members of the Carnegie Institution staff.

The next few years were devoted largely to the preparation of the Uaxactun report, which served as a Ph.D. thesis at Harvard in 1933 but was not published until 1937. During this period he made reconnaissance trips to various parts of Guatemala. He also undertook several minor excavations - twice at Quirigua, also at Kaminaljuyu on the outskirts of Guatemala City and at San Agustin Acasaguastlan.

In the spring of 1936, Ricketson left Guatemala for good, moving to New Mexico and, in the spring of 1937, to Ricketson's Point, South Dartmouth, Mass., where his family had lived for over two centuries. The following year he settled in Cambridge where he undertook a study of environmental problems bearing on the Maya area. In 1940 he obtained a leave of absence to attend to personal affairs and, after his divorce in 1941, he married Miss Anne Riggs.

At that time Ricketson had worked for the Carnegie Institution of Washington longer than any other individual except Dr. Morley. In the fall of 1941, however, his long career with the Institution was broken under circumstances he resented and he decided to retire from archaeology. Again he moved to Ricketson's Point, South Dartmouth.

During the war, in 1943, Ricketson was sent to Manaos, Brazil, with the imposing title of "Deputy Expedition Leader, Rubber Exploration Defense Supplies Corporation, American Republics Aviation, Reconstruction Finance Corporation." After some time in Brazil, however, he realized that the program was of little value and he resigned.

At the beginning of 1945, the Ricketsons moved to Boston and in April they made a trip to Yucatan, where they were the guests of Dr. S. G. Morley. Subsequently Ricketson set himself up as an illustrator and draftsman with an office in Cambridge, a business enterprise which was immediately successful. $\mathrm{He}$ illustrated books such as Hooton's Up From The. Ape, as well as drawings for commercial advertising. Eventually, however, he again retired to South Dartmouth.

In spite of his rural life, Ricketson never lost his basic interest in archaeology and travel. In 1946, he delivered a series of lectures on Latin America under the auspices of the Boston Pub- 
lic Library. For two winters he and his wife cruised to Florida and back in a 36-foot motor sailer. His last field work was the excavation of a colonial fort for the Old Dartmouth Historical Society. At the time of his death, he was hoping to enlist with some archaeological expedition to Central America for the winter of 1953.

It is typical of Ricketson's career as an archaeologist that he was the first in many and diverse achievements. He was on the first expedition devoted exclusively to the study of dendrochronology in the Southwest. He made the first adequate maps of many Maya cities and the first latitude and longitude surveys which located them accurately. He was an observer on the pioneer air-reconnaissance flight over the Maya lowlands. He was among the first to excavate at Chichen Itza, and he planned and initiated the Carnegie Institution's program in the Guatemalan highlands. His outstanding achievement was at Uaxactun where he excavated for years under most difficult conditions. As a result, he was one of the first to demonstrate the existence and nature of pre-classical Maya culture.

In regard to Ricketson's personality and character, "He was," states Professor E. A. Hooton, "one of the most charming and friendly men whom I have had the privilege of knowing. He was essentially straightforward and simple - in contrast to being devious and complicated - in his thoughts and in his behavior. He was, beyond most persons whom one knows, loyal in his relationships to his work and to his colleagues. His modesty was so marked as to constitute something of a handicap in his profession. People sometimes were inclined to take him at his own very humble estimate of himself, for his capabilities were in fact far greater than he was ready to admit."

Ricketson was a man of medium height, small boned and strongly muscled. He not only was an able illustrator, draftsman and surveyor but was dextrous with all tools. He was also an expert in navigating small boats as well as the handling and packing of mules. He was the most considerate travelling companion I have ever known, thoughtful, inventive and indefatigable. These were the qualities he needed, for life in Central America was primitive when he started work. Even in the cities, food was poor and accommodations inadequate. Apart from ox carts in the cities, all transportation was by pack mule or horse or by tump line on human backs. In the bush there were no resources except what an outfit carried with them. Ticks, fleas, malaria and dysentery were accepted and unpreventable evils. "To Dr. Ricketson's ability," wrote Dr. A. V. Kidder, "as an organizer and leader of expeditions into difficult country, and to his skill as a field archaeologist, is due a very large share of our present knowledge of the Maya Old Empire." 1

\section{S. K. LOTHROP \\ Peabody Museum \\ Cambridge, Mass.}

${ }^{1}$ Carnegie Institution of Washington Yearbook 41, p. 248 .

\section{BIBLIOGRAPHY}

1924. Report on the Excavations at Baking Pot, British Honduras, Carnegie Institution of Washington Yearbook, No. 23, pp. 219-21. Washington.

n.d. Index and map of ruins in the Maya area, (co-author, F Blom). Manuscript, 1924-25. Peabody Museum Library, Cambridge.

1925. Burials in the Maya area. American Anthropologist, n.s., Vol. 27, pp. 381-401. Menasha.

1925. Proverbs and Anecdotes from British Honduras. British Journal of Folk-lore.

1925. Report on the Repair of the Caracol (Station No. 5). Carnegie Institution of Washington Yearbook, No. 24, pp. 267-9. Washington.

1925. Report on the Temple of the Four Lintels (Station 7). Carnegie Institution of Washington Yearbook, No. 24, pp. 267-9. Washington.
1926. A "Greenwich" of Prehistoric America: the Ancient Maya Astronomical Observatory Discovered in Yucatan. Illustrated London News Nov. 20, 1926, pp. 982-83. London.

n.d. A brief history of Chichen Itza. Manuscript 1926-27(?). Peabody Museum Library, Cambridge.

1927. American Nail-less Houses in the Maya Bush. Art $\mathcal{B}$ Archaeology, Vol. 24, pp. 27-36. Washington.

1927. Report on the Uaxactun Project. Carnegie Institution of Washington Yearbook, No. 26; pp. 256-63. Washington.

1927. Las ruinas de Uaxactun ... traduccion de Carlos L. Luna. Sociedad de Geog. e Hist. de Guatemala. Anales. Vol, 3, pp. 417-21. Guatemala. 
1927. Sixteen carved panels from Chichen Itza (by E. B. Ricketson), with 16 original illustrations by O. G. Ricketson, Jr. Art \& Archaeology, Vol. 23, pp. 11-15. Washington.

1928. Astronomical Observatories in the Maya Area. Geographical Review, Vol. 18, pp. 215 25. New York.

1928. Eight Pottery Figurines from Guatemala. Art E Archaeology, Vol. 26, pp. 27-73, 82. Washington.

1928. Fresh Discoveries in Maya Exploration. Carnegie Institution of Washington Supplementary Publication. Washington.

1928. Notes on two Maya Astronomical Observatories. American Anthropologist, n.s., Vol. 30, pp. 434-44. Menasha.

1928. Report on the Uaxactun Project. Carnegie Institution of Washington Yearbook, No, 27, pp. 307-12. Washington.

1928. A Stratification of Remains at an Early Maya Site. National Academy of Sciences, Vol. 14, No. 7, pp. 505-8. Washington.

1929. Excavations at Baking Pot, British Honduras. Carnegie Institution of Washington Publication, No. 403. Washington.

1929. Report on Miscellaneous Excavations. Carnegie Institution of Washington Yearbook, No. 28, p. 323. Washington.

1929. Report on the Excavations at Uaxactun. Carnegie Institution of Washington Yearbook, No. 28, pp. 316-22. Washington.

1930. An Archaeological Reconnaissance by air in Central America (co-author, A. V. Kidder). Geographical Review, Vol. 20, pp. 177-206. New York.

1930. The Excavations at Uaxactun. 23rd International Congress of Americanists, New York, 1928. Proceedings. pp. $185-87$.

n.d. Information for Expeditions Based on Belize, British Honduras. Manuscript, 1931. Peabody Museum Library, Cambridge (co-authors, E. B. Ricketson and A. L. Smith).

1931. The Present Status of Archaeological Investigation in Guatemala. Carnegie Institution of Washington Yearbook, No. 30, pp. 112-14. Washington.

1932. Las excavaciones en Uaxactun. Soc. de Geog. e Hist. de Guatemala. Anales. Vol. 9, pp. 3457. Guatemala.

1932. Un nuevo aspecto en arqueologia. Soc. de Geog. e Hist. de Guatemala. Anales. Vol. 9, pp. 176-81.

1933. Excavations at Quirigua (summary). Carnegie Institution of Washington Yearbook, No. 32, pp. 95-96. Washington.

1933. Excavations at Uaxactun. Carnegie Institution of Washington Supplementary Publication, No. 6, pp. 1-15. Washington.
1933. Excavations at Uaxactun. Scientific Monthly, Vol. 37, pp. 72-86. Lancaster.

1933. Observations on the races of northern Guatemala, British Honduras, and the Highlands of Guatemala. Carnegie Institution of Washing. ton Publication, No. 431, pp. 184-89. Washing. ton.

1933. Stratigraphy and its Interpretation at Uaxactun. Ph.D. Thesis, Harvard College Library, Cambridge.

1935. Examples of British Honduras Stories, Prov. erbs and Riddles. Folklore, Vol. 46, pp. 284-90.

1935. Maya pottery well from Quirigua Farm, Guatemala. Maya Research, Vol. 2, pp. 103-5. New York.

1936. Ejemplos de anecdotas, proverbias y adivinanzas de Honduras Britanica. Soc. de Geog. e Hist. de Guatemala. Anales. Vol. 13, pp. 112 118. Guatemala.

1936. La institucion Carnegie de Washington en Guatemala. El Imparcial. Jenero 30 a Febrero 4, 1936. Guatemala.

1936. Ruins of Tzalcam, Guatemala. Maya Research, Vol. 3, pp. 18-23. New York.

n.d. Memoire ou Coup-d'oeil rapide sur mes differens voyages et mon sejour dans la nation creck, by General Le Clerc Milfort. Paris, 1802. Translated into English with explanatory notes by O. G. Ricketson, Jr. Manuscript, 1937. Peabody Museum Library, Cambridge.

1937. Uaxactun, Guatemala. Group E-1946-1931, (co-author E. B. Ricketson). Carnegie Institution of Washington Publication, No. 477. Washington.

1939. Municipal organization of an Indian township in Guatemala. Geographical Reqiew. Vol. 29, pp. 643-47. New York.

1940. An Outline of Basic Physical Factors Affecting Middle America. In "The Maya and Their Neighbors." Pp. 10-31. New York.

1940. The Cuchumatanes Re-visited. Scientific Monthly, Vol. 51, pp. 341-57. New York.

1943. Notes on the Pacaguara Indians of the Rio Madeira and their language. Mimeographed. Prepared for the Exploration Dept. Rubber Development Corp. R.F.C. Containing a PanneEnglish vocabulary and a Pakaguara-English vocabulary.

In addition to the above list, Ricketson submitted to the Guatemalan government annual detailed reports of all excavations with plans and photographs. Copies are in the files of the Carnegie Institution of Washington. Presumably these reports contain material which has not been published. 